\title{
SOCIO-COMMUNICATIVE DIMENSION OF TELEVISION DEVELOPMENT
}

\author{
Olha Yatchuk ${ }^{1}$ \\ Natalia Kodatska ${ }^{2}$
}

DOI: https://doi.org/10.30525/978-9934-588-15-0-147

\begin{abstract}
The purpose of the paper is forming of a certain concept of periodization in television development in the context of social and communication features of broadcasting, which would be based on the following aspects: technological, content and communication. The survey is based on integrated approach to the use of theoretical, empirical, empirical-theoretical, analytical research methods and sectoral methods of social communications. Historical and comparative historical methods have been used to analyze and systematize data on the formation and development of television and its individual broadcasting models (on-line and off-line). Systematization, classification, and grouping were used to identify features and factors of television development in individual models. The comparison method was used to identify common and distinct features of different stages of television broadcasting. The content analysis method was used to systematize data on the development of on-line and off-line models as communicative television technologies. Results of the survey is comprehensively understanding the phenomenon of television development as a space to meet the social and communicative needs of society. Analyzing and understanding the main stages of television development as a communication system will improve the quality of the study of individual issues related to television, as well as help predict the future vectors of development of this communicative phenomenon. The issue is changing the traditional paradigm of television as a communication space influenced by electronic media and internet communication, with convergence and new
\end{abstract}

\footnotetext{
${ }^{1} \mathrm{PhD}$ in Social Communication, Associate Professor of the Department of Journalism, Philosophy and Social Communications,

University of Customs and Finance, Ukraine

${ }^{2} \mathrm{PhD}$ in Sociology, Associate Professor of the Department

of International Economic Relations, Regional Studies and Tourism,

University of Customs and Finance, Ukraine
}

(C) Olha Yatchuk, Natalia Kodatska 
technologies that directly change the content of television space. Practical implications of research are in summarizing the observations on the development of different models of television, as well as television in general, show that the fluctuation of the interest of the viewer and producer to each of them depends on the state of technological development, political and communication tasks. Using the periodization of television development offered by various researchers in the content analysis, we have recorded a new stage of television development, which is related to the impact of Internet communication, which we have designated as the "period of media integration" - eradicating a new technological component (Internet), the emergence of new content and a new format for viewer engagement that extends beyond television communications. The value of research lies in defining and justifying changes in television content that tend to complicate creative, technological and communication influences, and engagement with the viewer changes from watching and mediating reactions to television programs to direct communication and interaction.

\section{Introduction}

The history of Ukrainian television in the context of world television development in general remains is a poorly understood topic for researchers of the theory and history of social communications and media. Analyzing and comprehending the major stages of television development as a communication system will improve the quality of the study of particular issues related to television, and will help predict the future vectors of development of this communicative phenomenon. This issue becomes important especially in the age of electronic media and the impact of Internet communication, with convergence and new technologies affecting traditional television models.

The source of the study is the history of world and national television. The purpose of our study is due to the need to formulate a certain concept of periodization of television development in the context of social and communication features of broadcasting, taking into account technological, content and communication aspects. According to the purpose of the article we have set the following tasks:

- to study and propose a concept for television development that would meet the requirements of the development of communication technologies; 
- to identify the factors that influenced television at each stage of its formation;

- to track the development of the off-line and off-line models in the context of historical technological and communicative changes in society;

- to distinguish the communicative component of interaction with the viewer at each stage of television development;

- to identify further research vectors related to television functioning in general.

The realization of the goal and objectives of the research determine the complex approach to the use of theoretical, empirical, empirical-theoretical, analytical methods of research and sectoral methods of social communications. Historical and comparative historical methods have been used to analyze and systematize data on the formation and development of television and its individual broadcasting models (on-line and offline). Systematization, classification, and grouping were used to identify features and factors of television development in individual models. The comparison method was used to identify common and distinct features of different stages of television broadcasting. The comparison method was used to identify common and distinct features of different stages of television broadcasting. The content analysis method was used to systematize data on the development of on-line and off-line models as communicative television technologies.

\section{Development of two broadcasting models (on-line and off-line)}

Television originated from a technical invention, and the main purpose of this discovery for the society was the ability to transmit the image at a distance. People not only receive a new technical device, but also a completely new cultural, social, linguistic paradigm, which over time will change the nature of man and his ability to perceive information. It should be noted that the first development and the first successful experimental attempts were based on the transmission of the signal on-line, that is, the moment of content creation and its reception coincided in real time:

- USA: New York opened the opening of the World's Fair, where US President FD Roosevelt April 30, 1939 [2, p. 9-10];

- United Kingdom: The BBC used off-camera footage to cover sports tennis, yacht racing, football - but the most important highlight in 1937 was 
the live broadcast of the coronation of George VI, which is considered to be the greatest achievement of live coverage [2, p. 39];

- Germany: during the 1936 Summer Olympics, live broadcasts were broadcast live for 8 hours a day and were broadcasted via coaxial communication by residents of not only Berlin but also Hamburg, Leipzig, Nuremberg, Munich and Cologne [2, p. 57].

New technological advances and online communication make the model online, with its interactivity appealing to the viewer, albeit more demanding for manufacturers than the project without the feedback shown on the record. The viewer's participation in the formation of television content corresponds to the socio-psychological attitudes of the modern open society, therefore, it is effective in terms of the formation of television content of modern TV channels.

Therefore, the communication characteristic of the model on-line is the possibility of direct interaction with the viewer, this property is provided by the following factors:

- the viewer is a direct participant in the event (story). It is about the role of the witness-witness in the information broadcast, the socialization with the community during telethon, the role of the "virtual judge" in entertaining shows in the form of comments on events witnessed by the viewer through Internet communications;

- Feedback allows you to influence the results of studio projects directly by the viewer (the viewer can participate in surveys, engage in conversation, speak on the subject of the program through Internet communication).

- the time of interaction with the viewer is equal to the time of broadcasting a television product;

- self-identification of a person within the framework of the "I - community" model;

- the reaction to the program as it is viewed gives the television product a new role, creating variant finals in the future.

Open text and real-time overlays for viewers and TVs activate the viewership by forming their own audience for a particular communication channel. Thus, we see that almost all the leading countries in the world have used the opportunities of live television in the formation of unique telecontent. This model is characterized by open real-time overlapping text for viewers and TVs, resulting in increased viewership, script variability, and 
certain restrictions on genre use, visuals, and message editing. New technological assets and Internet communication make the model on-line thanks to its interactivity promising in the context of the problem of formation of actual telecontent.

In the initial phase of television, the on-line model gave way to an offline model, enabling editing of messages, reproduction of reality through specific forms of editing and shooting, while at the same time using complex scripted forms, not limited by time and space characteristics. This change in models is evidenced by facts from television history, including Ukrainian history.

The history of Ukrainian electronic television begins with the date of commissioning of the television center on Khreshchatyk, 26. According to I.G. Mashchenko in the Encyclopedia of Electronic Mass Media [4, p. 180], on the day of its first airing, the feature film "The Great Zagreva" was shown, and the very next day the workers of the Kiev TV Center rolled out two studio cameras on Khreshchatyk and broadcasted a military parade and demonstrations on the occasion of the October Revolution. This historical fact testifies that two broadcasting models - live broadcast and prepared screen product - coexisted in Ukrainian television from the very beginning. However, the situation has changed over time.

The development of video tapes and VCRs, initiated in the 1950s in the United States and the early 1960s in the USSR, was the impetus for the increase in the number of pre-recording programs. This made it possible, on the one hand, to delay the demonstration of the program and, on the other, to use editing and shooting capabilities, to improve telematic power. Therefore, technologies for preparing programs for broadcasting, editing, video recording have gradually evolved, and programs that undergo editing and editing remain traditionally a priority in modern TV space. These are pre-prepared texts that meet the requirements of the audience, can combine several events at one time, have complex special effects and editing clutches, the language of these programs using the techniques of directing and shooting approaches cinema.

Thus, the off-line model is a technology of formation of the screen product for which the moment of creation of content and its reception do not coincide in real time, there is an expanded possibility for reproduction of the screen image by means of editing. As a result, there is a great ability to 
edit not only messages but also video. Most TV journalism genres consider this model: it has a clear, closed and inviolable form of script, and is the result of the process of television reproduction of an event.

The main purpose of the off-line model programs is the one-vector transmission of certain messages, in the communication act with the viewer the feedback is not taken into account or is not dominant. Summarizing, we can say that this model is characterized by the following features:

- the viewer belongs to the role of the observer, the television content is used by him for pleasure, performing informative, integrative or recreational function;

- there is a possibility of feedback (every program or TV channel has an actual address, contact telephones, sites, etc.), but it does not allow to influence the results of programs / projects directly by the viewer (the viewer can write a review or leave a questionnaire for participation in various projects, to speak on the subject of the program through Internet communication, if there are certain conditions for this);

- the interaction with the viewer is probable only after watching the program, it does not coincide with the time of the television broadcast;

- continuing introverted self-actualization of the person with the immersion in their own feelings;

- feedback on viewing a program appears more often as a result of measuring the audience interested in a screen product.

The main difference between producing off-line models is the ability to edit teletext that applies to the script, text strategies, visuals and timeline. Installation becomes the way of life of this model.

So, we see that the development of video tapes and VCRs (50-60's) has given a new impetus to increasing the number of pre-recording programs. The two broadcasting models coexisted from the outset, but differed in capabilities and effects. The off-line model as a technology for forming a screen product for which the moment of content creation and its reception does not coincide in real time, the main purpose is one-vector transmission of certain messages, the communication act with the viewer does not take into account the feedback or it is not dominant. The main difference between off-line programs is the ability to edit teletext that applies to scripts, text strategies, visuals, and timelines. Editing becomes the way of existence of this model and allows to distinguish such editing functions as technical, 
semantic, dramatic, visual and strategic. For the off-line model audience, there is a certain concept of the audience's expectations of the likely finale.

\section{The history of television. The experimental period}

The periodization of television development history in the context of complex research has been considered by various scholars. Thus, I. Katsev [3] proposed periodization of domestic television, distinguishing 4 stages and focusing on the creative process: technical experiments (1907-1957); acquisition of own means of expression (1957-1970); the period of rigid censorship (1970-1985) and stagnation (1985-2000). A. Fortunatov [8] distinguished 3 stages, focusing on technical development and communicative aspects: the period of formation (1883 - the end of the 30 -ies); TV as an independent phenomenon and a social institute (40-80 years); the period of digitalization and convergence (lasts from the 80's). M. Golyadkin [2] distinguishes 4 stages, which are connected with time, technology development and improvement of genre palette of this type of communication: experimental stage (30-40 years), formation period (50-60 years), TV as a means of communication (70-80 years) and television content (from the 90 s to the present).

As part of this study, the conception of M. Golyadkin as the one that most adequately reflects the development of telecommunications technologies is adopted to periodize the history of television development. Accordingly, each stage has its own constitutional features. For the experimental broadcasting period, the characteristic features are:

- the process of adopting common broadcasting standards;

- the origin of the main types of broadcasting: information (photo newspapers in the USSR, analogs of news, sports events, reports from the scene, etc.); political and public (in Germany invited politicians to the studio); entertaining (cinema, theatrical and musical performances with the participation of famous actors); and even children and youth (Great Britain showed animation films, Germany - youth programs, the USSR - children's performances) [2, p. 9-57];

- live coverage of the event attracts more than 150,000 viewers at the 1936 Olympics in Germany;

- the programs are cultural and educational in nature (most of the broadcasting is occupied by performances, performances by actors, screenings); 
- a small number of television sets in the population - from 500 (France) to 15 thousand (Great Britain), the largest number by saturation of radios and TVs before the Second World War was Germany [4, p. 108-113];

- the first audience research and skeptical Attitude to TV. Gallup, a US audience survey, found that in $1939,87 \%$ of the population considered television superfluous, and by the end of $1945,81 \%$ of Americans had never seen television before, although 10 television stations and 6,000 people worked in the country [4, p. 117].

In general, in the first stage of television development, we can outline 3 directions of experimental action related to the following: 1) the development of a technological component (mechanical and electronic television); 2) content development (live broadcasts, speeches, etc.); 3) with interaction with the viewer (audience research and production of receivers in the amateur way - during the era of mechanical television in the territory of the USSR, there were almost 2000 receivers collected in the amateur way). The off-line model is implemented mainly in the form of closed cultural texts. The development of the model on-line is experimental in nature, the technology of live broadcasting is actively developing. The outbreak of World War II hindered the development of television.

\section{Television History. Formation Period}

The second phase begins after 1945, related to the resumption of broadcasts and the operation of television in general. From 1946 to 1954, television broadcasting was restored in all the leading countries of the world - the period of television broadcasting began, characterized by:

- international influence. Establish links between countries using radio relay frequencies, and set up international television organizations (eg OIPT and Interbay);

- professional staff. Creative workers come from related industries, have philological, theatrical and film education, appear universities, which train specialists;

- the invention of VCRs had a huge impact on the further development of the model off-line: in 1956, the American channel CBS uses a VCR to delay the evening news, and after 4 years of the USSR Central Television for the first time broadcast a concert recorded on the first Soviet-style video recorder [2, p. 21, 99]. The first television films and series appear, but studio 
cameras are still quite heavy and do not allow mobile movement, so the active development of this model is still ahead;

- development of model capabilities on-line. In addition to broadcasting live reports, there is a dialogue: Triangle (Tallinn, 1965), Business Meetings Club (Perm, 1967), Seven Fair (Polish TV). The telemaster was also set up: On July 24, 1962, more than 180 million Americans and 100 million Europeans saw US President John Kennedy deliver a press conference with the help of Telemachus, with American and European viewers participating [6, p. 12]. Entertainment broadcast attracts the audience for the results: in 1964, in France during the program "Man of the Twentieth Century" viewers, trying to answer the presenter's questions, call and block the telephone network of Paris (at the same time more than 100 thousand people). At the same time, Czech television, with the participation of the viewers, is conducting the song contest for tomorrow [6, p. 12-13]. Live broadcasts are also used in news broadcasts: during the "Relay Relay" program in the mode of "direct inclusion" involved local television studios of the country, and in 1967 its author Yu. Fokin makes a screen list of studios "USSR-67. One hour of life of the Motherland », uniting more than 30 cities of the USSR [4, p. 216, 233]. However, for the USSR during this period, the development of the on-line model became a feature of local television studios, as T. Shalman defines, only "exclusively on regional television. On the central television screen, interaction with the audience was allowed only very limited, only in a few entertainment and educational programs" [9, p. 40];

- growing television audience in the world. The dynamics of the development of telecommunications in the USSR is evidenced by the fact that in 1953 there are three television centers in Moscow, Leningrad and Kiev with 120 thousand television sets, and after 5 years in 3258 centers and 1 million 760 thousand TV sets [11, p. 30];

- study audience and effects of TV. A systematic audience study begins and major research schools are formed to study the impact and effects of television both in the US and Europe. For domestic journalism, this period is connected with the emergence of universities and the development of scientific research in the field of television communication (analysis of television is presented in the first studies by R. Boretsky [1], V. Sappak [7], O. Yurovsky [10] and others). 
Thus, in the period of the formation of television, development proceeds in 3 directions: technological components of broadcasting (standardization, influence of space technologies); Content (unique TV genres: TV series, talk shows, etc.) viewer interaction (systematic study of audience and effects of $\mathrm{TV}$, experimental nature is the use of viewer interaction (telephone polling during the broadcast). The model off-line extends the capabilities and genre palette by recording on the VCR. The development of the model on-line associated with international broadcasts and dialogic genres that are widely used in regional broadcasting.

\section{History of television. Globalization period}

Continuing trends that began in the 50s and 60s, 70-80s is recognized as a global medium of communication. This is evidenced by the joint international conventions and declarations adopted by the Council of Europe and the UN General Assembly: the Council of Europe Declaration on the Freedom of Expression of Views and Information (1982), the Convention on the Principles of the Use by States of Artificial Satellites of the Earth for Direct Television Broadcasting (1982) ) and other documents. The characteristic features of this period are:

- development of satellite broadcasting and frequency distribution, experimental developments in high-definition television (HDTV) and stereo-TV;

- segmentation of television space. Parliamentary channels, public service broadcasting, and highly specialized channels appear: CNN (1980), MTV (1981), Eurosport (1989); TV channels broadcasting via satellite; segmented airtime within one TV channel by time; morning, evening or nighttime programs appear, for example, «in the morning» of 1987, «the evening before and after midnight» projects were available at the USSR Central Committee;

- The topic of programs is expanding. Educational cycles appear. For example, BBC-2 in 1971 introduced a new form of correspondence "Open University" with the award of a bachelor's degree [4, p. 244];

- the on-line model extends interaction to intercontinental cooperation; Spectators actively cooperate with television - during a TV quiz on MTV's Wall Dellen High School Cruise Championship in 1983, a record number of telephone responses was received - 80,799 [4, p. 281]. "Direct inclusions" 
become a new feature of news broadcasting, but television for the first time becomes a place of demonstration of cruelty: during the live broadcast, the Spanish government is taken hostage by hostages, and during the Cairo military parade, «Muslim Brotherhood groups» attacked the President and those present;

- the off-line model continues to refine genre forms: the production of films specifically for television is actively developing. Yes, I.G. Mashchenko noted that in 1985 the release of feature television films (series) at Ukrainian film studios for the first time exceeded the production of tapes for screening in cinemas [4, p. 288]. The Western viewer is in particular demand for Docudrama documentary TV projects, based on documentary material but reproduced by the artistic means of television: court cases, 911 rescue service events, and more. Under the influence of cinematography, it becomes more complex to telematic, and the quality of the video series improves.

- audience research continues: The introduction of pillmetry by the British company AGB (Audits of Great Britain) in 1984 is a new step. This made it possible to take into account every 5 minutes the switching on and switching of channels (the number of which could be up to 97 at a time) and to transmit feedback data by telephone, in the early 90 s this system was used throughout Europe [12]. The USSR used only sociological methods of mail analysis, for example, the State Television and Radio of the USSR created a department of letters for recording, studying and analyzing correspondence of viewers and listeners [4, p. 260].

Thus, we see that the recognition of television as a medium of communication is on an international scale, its capabilities are being improved in 3 ways: the technological component is complemented by satellite communication; content expands, market segmentation occurs; engagement with the viewer enhances the audience learning system, introduces pillmetry and ratings. The off-line model complicates the telematic, the tendency to destroy the broadcasting program and receive custom materials, by pre-recording the VCR with a separate viewer. The development of the model on-line during this period is associated with "bridges" and live broadcasts, especially sports competitions such as the Olympics. For the first time, live broadcasts go beyond editorial influence, demonstrating live attacks. 
Globalization as a cultural process is contradictory. From one on the other hand, it is positive because it brings people, states, peoples closer, opens up new opportunities for them, modernizes, intellectualizes them life and thoughts. Otherwise, globalization is negative because leads to the universalization of such phenomena as terrorism, extremism, aggressive separatism, man-made catastrophism, nationalism, and in general, all the problems of modern civilization (environmental, energy, demographics). Countries or social organisms fail pressing the new global pyramid - degrading, corrupt and collapsing, actually being under the rule of the class-mafia structures. In this case, globalization complicates human being, brings a person closer to suffering and uncertainty. But, the negative ones the effects of globalization can by no means be absolutized, together with the complications inherent in globalization, it has positives moments. Globalization ensures the integration of peoples and states into one space, which helps them solve their life problems effectively by means of changing human existence. According to the writer and the publicist Mario Vergas Llosa, "Globalization is expanding horizons individual freedom" [12, p. 54]. On the other hand, a person is influenced global processes lose their identity, the foundations of identity.

The direction of globalization as well should be discussed separately formation of a single global information space. It is widely believed that the development of modern IT has given a strong impetus to accelerating the process of borrowing cultural and institutional and on this basis a certain universalization of the forms of the public life. Essentially, this is a widespread introduction of basic ones social values, institutional arrangements and cultural models, that are peculiar to the countries of the West, especially the USA [14]. Currently the leading countries the world and multinationals are making extensive use of new ones opportunities in this field to realize their own political, economic, socio-philosophical interests. Along with this powerful feeds based on the latest technologies, targeting different countries and cultural communities; a powerful, unmanaged flow of carrier information is updated relevant symbols, cultural specimens. As a result of such expansion there is a destruction of traditional sociocultural forms and institutes.

\section{History of television. The period of telecast}

Individual devices for satellite reception, cable television, segmented markets and the emergence of pay-TV services are leading to TV content 
and the development of the television industry. The development of digital broadcasting and the construction of new national television networks (a process to which Ukraine is involved), the development of HDTV, satellite communication systems and the integration of Internet communications and television are a hallmark of the period beginning in the 1990s. For this period the characteristic features are:

- legal regulation of TV channels: in the USA in 1996 the Communication Act was replaced by the Communication Act (1934), significant changes were made to the basic and competition provisions in all types of communication (including the Internet); during this period Ukraine adopts a number of laws in the field of telecommunications regulation; the Council of Europe Parliamentary Assembly adopts resolutions on the rights and principles of television journalists' activities;

- increasing the number of commercial TV companies, especially in the post-Soviet space. The example of Ukraine shows the dynamics: 1990 the first non-state regional television company "Tonis Center" ("Channel 7") in Kharkiv, in 1998 the National Council for Television and Radio Broadcasting registered 516 broadcasting organizations in Ukraine, and in 2005 there are already 1268 broadcasters licensed to broadcast;

- the on-line model in information broadcasting begins to use live broadcasts to wage information wars: the constitutional crisis of power in Russia in 1993, the coverage of the Iraq war (2003), the events of the 2004 Orange Revolution in Ukraine, and others. Democratization on the air of perestroika times was approved through live broadcasting programs. The Reality-Show genre appears in the entertainment broadcast;

- the off-line model remains basic for manufacturers, the complexity of formats continues, the attraction to entertaining broadcasting is observed;

- audience surveys are expanding internationally - in 1991, the London Institute of Communication analyzed evening news in 55 countries on 97 TV channels; research is being conducted in new countries, and in 1997 SOCIS Gallup International began to analyze television audiences in Ukraine as well [4, p. 313, 336].

Thus, in the period of telecasting, the expansion of television capabilities in 3 directions also continues: the technological component is being improved with digital broadcasting and high-definition television (HDTV, HDTV); content continues to expand (Reality-Show genre appears); audience research 
goes beyond one country, extends to new countries, including Ukraine. The off-line model remains basic to manufacturers and complicates formats (especially in entertainment). Within the on-line model, the Reality-Show genre developed during this period and "information wars" continued.

\section{History of television. Media Integration Period}

But active development of Internet communication, social networks, new opportunities that get traditional media integrating into the Internet allow us to predict the next stage of television development - this is a certain period of media integration. In our opinion, it is just getting started, so all new influences on Internet content from telecontent, new audience studies that allow more thorough user experience while engaging with content are opening new avenues for further exploration of television and social communication in general.

Analyzing the current state of television development, we see that a new technological component (the Internet) is actively influencing the viewer. This creates a new type of content where the participation and role of the viewer change - from event watcher to active participant (a prime example is the various Life-Show live broadcasts where viewers are involved in the conversation), in addition we see a new type of communication, with the integrating features of television and internet communication in general.

Increasing the number of Internet users and its speed, it is possible to form a new type of media content consumers, as evidenced by the popularity of various video hosting services, the rapid increase in the number of mobile devices that allow to expand the limits of content consumption - without limiting itself to broadcast TV channels on demand (Video on Demand (VOD), live view (on-line). This confirms the validity of a new approach to understanding the interaction between journalists and consumers of information - a conceptualization of journalism based on the identity construct offered by American researcher R.D. Mercy [13]. This is how journalists understand their audience and, as members of that audience, connect with their communities.

Integrated journalism is known to consist of three stages: gathering, editing and disseminating information. However, the influence of the Internet allows the consumer to play his or her role at each stage, thus helping the journalist determine the degree of "relevance" of the story to himself and to 
the potential audience. All this works to the working hypothesis that interactive television, as a key television communication, contributes to the further development of media culture among viewers, since experience and a certain critical attitude to information are specific to an audience with a certain level of media education. Updating public journalism confirms the relevance of this hypothesis, especially in the context of interactive broadcasting.

These trends are confirmed in the materials of David Poltrak's report "The Outlook for the Broadcast Networks" at the UBS Global Media conference, the American television market is characterized by "interactivity with the viewer": it is fixed that almost $60 \%$ viewers while watching television programs "communicated or searched for" information about the same program [14, p. 127].

The new development of real television, on-line broadcasting in various social networks and applications once again bring some interest to the life of a real character in today's world. So researcher Podebonostseva believes that real television is the direct heir to television as such: from a living person who speaks to an audience on the air, moreover, not only through words but also through eyes, gestures, facial expressions, television has been transformed into different formats of real show. These are shows that make a spectacle of the lives of ordinary people. 5-10 years ago, such programs were based on stories, testimonies, confessions of people who wanted to share their personal problems, but today we see that social networks and blogging open up new opportunities for interaction with the producer of audiovisual work (or content). And anyone can become this manufacturer.

Irina Pobedonostseva believes that the real show is one of the TV formats that fully implements the ideology of interactivity, as the audience throws the candidates out of the game and influences its further development [5, p. 167], when viewers begin to rate the contestants, the projects go live, and after a while, in the continuation of the same live broadcast, we find out who is leaving the project - so the on-line model is used.

\section{Conclusions}

Thus, we see that the socio-communicative dimension of television in Ukraine must be viewed in the context of historiographical and theoretical-methodological studies, in the context of mass-communication processes. The essence of television and its particular problems have often 
been the focus of many researchers, and it is almost impossible to distinguish the industry or range of issues that remain beyond the reach of scientists. Observance of the objectively chronological sequence of events, phenomena and facts, the use of general methodology and methods of scientific research allows to form a television concept combining 2 models of broadcasting on-line and off-line. The on-line model is characterized by open text and real-time overlapping for viewers and TVs, leading to a more active audience. The off-line model is the technology of forming a screen product for which the moment of content creation and its receiving do not coincide in real time.

The periodization of television development distinguishes 5 stages: experimental broadcasting; becoming; TV as a means of communication; tele-wealth and the current state of development, collectively called the integration period. Each period is characterized by a tendency to develop in 3 general directions: technological, content development and development of interaction with the viewer. The achievements of each period and the improvement of technological aspects (television standards, signal transmission, satellite communications, improvements in technology, video, etc.) influenced the development of on-and-offline broadcasting models. Generalizations of observations on the development of television models indicate that the fluctuation of interest in each of them depends on the state of technological development, political and communication tasks. Television content tends to complicate the creative, technological and communication impact, and interaction with the viewer changes from watching and mediating the reaction to the television program to direct communication and interaction.

\section{References:}

1. Boretskiy R.L. (1961). Informatsionnyye zhanry televideniya [Informational genres of television]. Moscow: Art. (in Russian)

2. Fortunatov A.N. (2006). Problemy istorii televideniya: filosofskiy $i$ kul'turologicheskiy podkhod [Problems of the history of television: philosophical and culturological approach]. Nizhny Novgorod: Nizhegor Publishing House humanitarian center. (in Russian)

3. Gane R. (1994). Television audience measurement in Europe. A review and comparison. London: Routledge.

4. Golyadkin N.A. (2004). Istoriya otechestvennogo $i$ zarubezhnogo televideniya [History of domestic and foreign television]. Moscow: Aspect Press. (in Russian) 
5. Katsev I.G. (2004). Istoriya rossiyskogo televideniya (1907-2000) [History of Russian television (1907-2000)]. Moscow: Russian State Humanitarian University. (in Russian)

6. Mashchenko I.H. (2006). Entsyklopediya elektronnykh mas-media [Encyclopedia of electronic media] (Vol. 1). Zaporizhzhya: Dyke Pole. (in Ukrainian)

7. Mersey R.D. (2010). Can Journalism Be Saved? Rediscovering America's Appetite for News. NY: Praeger.

8. Poltrack D.F. (2012). The Outlook for the Broadcast Networks. Retrieved from: https://www.cbscorporation.com/wp-content/uploads/legacy_corp/mce files/UBSFinal-WithNotes-dp-12-6-10.pdf

9. Pobedonostseva I.Ye. Televiziynyy dyskurs u kul'turnomu prostori postmodernizmu [The Television Discourse in the Cultural Space of Postmodernism]. (Candidate's thesis). Kyiv. (in Ukrainian)

10. Pobereznikova E.V (2004). Televideniye vzaimodeystviya: interaktivnoye pole obshcheniya [Television interaction: an interactive communication field]. Moscow: Aspect Press. (in Russian)

11. Sappak V.S. (1988). Televideniye i my: 4 besedy [Television and us: 4 conversations]. Moscow: Art. (in Russian)

12. Shal'man T.M. (2012). Spetsyfika y osoblyvosti rankovykh teleprohram $\mathrm{v}$ ukrayins'komu mediaprostori [Specificity and features of morning television programs in the Ukrainian media space]. Scientific notes of the Institute of Journalism, vol. 47, pp. 42-46. (in Ukrainian)

13. Yatchuk O. (2018). Interaktyvne telebachennya: sotsial'no-komunikatsiyni modeli ta tekhnolohiyi [Interactive Television: Social Communication Models and Technologies]. Dnipro: UMCF. (in Ukrainian)

14. Yurovskiy A.Ya. (1965). Ob iskusstve televideniya [On the art of television]. Moscow: Knowledge. (in Russian) 